\title{
Functional Salad Dressing as an Excipient Food
}

\author{
Sibel Karakaya*, Sedef Nehir El, Sebnem Simsek \\ Department of Food Engineering, Faculty of Engineering, Ege University, 35100 Izmir, Turkey
}

\section{A R T I C L E I N F O}

\section{Article history:}

Received 10 July 2015

Accepted 07 September 2015

Available online, ISSN: $2148-127 \mathrm{X}$

\section{Keywords.}

Caseinomacropeptide

Germination

ACE inhibitory activity

In vitro antidiabetic activity

In vitro bile acid binding capacity

${ }^{*}$ Corresponding Author:

E-mail: sibel.karakaya@ege.edu.tr

\section{A B S T R A C T}

The aim of this study is to develop salad dressing as an excipient food that can be used to enhance beneficial effects of salads when co-ingested together. The compounds that include bioactive constituents different from other salad dressings are germinated seed and sprouts of lentils and cowpeas, and caseinomacropeptide isolated from whey. The proximate composition, total phenols and total flavonoids of salad dressing were determined. Its beneficial effects on health (antioxidant activity, antidiabetic activity, bile acid binding capacity, and angiotensin converting enzyme inhibitory activity) were determined using in vitro methods. Energy value of salad dressing is $111 \mathrm{kcal} / 100 \mathrm{~g}$ and $11.41 \%$ of the energy value of the salad dressing is provided by protein. Total phenol content is $79 \mathrm{mg} \mathrm{CE} / 100 \mathrm{~g}$. Salad dressing displayed higher antioxidant activity against DPPH radical (130 mM Trolox/100 g) than that of ORAC value (72 mM Trolox/100 g). Salad dressing inhibited ACE by approximately 37\%. Expected glycemic index of salad dressing was 74.0 and belongs to high glycemic index foods. Contrary to, salad dressing inhibited $\alpha$-glucosidase and $\alpha$-amylase with the $\mathrm{IC}_{50}$ values $1.77 \mathrm{mg}$ protein $/ \mathrm{mL}$ and 2.40 $\mathrm{mg}$ protein $/ \mathrm{mL}$, respectively. Relative to cholestyramine, bile acid binding capacity of salad dressing is $39.85 \%$.

\section{Introduction}

Demand towards foods with health benefits has been increased due to utilize bioactive compounds in order to prevent diet-related chronic diseases such as obesity, diabetes, hypertension, heart diseases and cancer (Magrano et al., 2013; Chen et al., 2014). Vegetables and legumes are good examples for these foods. Healthpromoting functional characteristics of vegetables are mainly due to their functional bioactive constituents including vitamins, minerals and phytochemicals. These effects can be listed as antioxidant activity, cholesterol binding capacity, antidiabetic activity and angiotensin converting enzyme (ACE) inhibitory activity (Simsek et al., 2014). Epidemiological and clinical studies have shown that legumes have health benefits including lipid homeostasis control, hypocholesterolemic effect, glycemic control, anticarcinogenic effects (protease inhibitors and lectins), therapeutic effects ( $\alpha$-amylase and protein inhibitors on obesity and diabetes) and antioxidant activities (Akillioglu and Karakaya, 2010; Simsek et al., 2014). Germination is one of the biochemical reactions that cause enhancement of nutritional value and health effects of cereals and legumes (Kavas and El, 1992).

Bioactive peptides derived from food and other sources have been a focus of functional food research. Their activity in vitro and in vivo has mostly revealed antioxidant and anti-hyper/hypotensive effects (Guangchang et al., 2012). One of the bioactive peptides liberated from $\kappa$-casein during cheese manufacturing is caseinomacropeptide (CMP) or glycomacropeptide (GMP). Next to $\beta$-lactoglobulin and $\alpha$-lactalbumin, CMP is the most abundant protein/peptide in whey proteins. Recently, extensive research has highlighted the beneficial effects of CMP including interactions with toxins, viruses, and bacteria, modulation of immune system responses, promotion of bifidobacterial growth, suppression of gastric secretions and regulation of blood circulation (Thomä-Worringer et al., 2006). CMP has been reported to stimulate the release of cholecystokinin, the satiety hormone involved in controlling food intake and digestion in the duodenum of animals and humans (Yvon et al., 1994). Therefore CMP is considered a potential ingredient for functional food concepts (Tolkach and Kulozik, 2005).

The main concern regarding functional foods is bioavailability of bioactive compounds incorporated into commercial food products. The bioavailability of many of these bioactive compounds can be low due to low watersolubility, high melting point and poor chemical stability. The current opinion to improve bioaccessibility and bioavailability is to design food matrix (McClements, 2015). One of them is enhancing beneficial effect through excipient foods. The idea is combining food with another food (the excipient food) whose composition and/or structure is specially designed to improve health benefits 
(McClements and Xiao, 2014; McClements, 2015). McClements (2015) gave potential examples to excipient foods containing nutraceuticals with increased bioavailability. Salad dressing is one of the examples that can increase carotenoid bioavailability of leafy greens when co-ingested together.

The aim of this study is to produce salad dressing as an excipient food that can be used to enhance beneficial effects of salads when co-ingested together. To increase content of bioactives, germinated seed and sprouts of lentils and cowpea, and CMP, isolated from whey, are added to the recipe. Beneficial effects have been evaluated by determining antioxidant activity, in vitro antidiabetic activity, in vitro ACE inhibitory activity and in vitro bile acid binding capacity. In addition its proximate composition, and total phenols, total flavonoids are determined.

\section{Materials and methods}

Materials

2,2'-Azobis

(2-methylpropionamidine) dihydrochloride (AAPH) (440914), fluorescein sodium salt (FL 46960), Trolox (6-hydroxy-2,5,7,8 tetramethychroman-2-carbonsaure) (23.881-3), angiotensin converting enzyme from rabbit lung (ACE) (A6778), N-Hippuryl-His-Leu hydrate (H1635), 2,2Diphenyl-1-picryl-hydrazyl (DPPH) (D9132), Folin \& Ciocalteu's phenol reagent (F9252), (+)-catechin hydrate, 4-Nitrophenyl $\alpha$-D-glucopyranoside (PNPG) (N1377), mammalian $\alpha$-glucosidase (intestinal acetone powders from rat) (I1630), deoxycholic acid (D2510), cholic acid (C1129), taurocholic acid sodium salt hydrate (T4009), glycocholic acid hydrate (G2878), pancreatin (P7545), pepsin from porcine gastric mucosa (P7000) were purchased from Sigma Chemical Co. (St. Louis, MO, USA). Bile Acid Diagnostic Kits were purchased from Trinity Biotech plc, Bray Co. (Wicklow, Ireland). All other chemicals were of analytical grade. All vegetables, cowpea and lentil were purchased from local markets in Izmir, Turkey. Whey was kindly supplied by Yasar Holding Food and Beverage Group, Izmir Turkey.

\section{Methods}

All analyses were performed as triplicate and two parallels.

\section{Germination}

Green lentils (Lens culinaris $\mathrm{M}$.) and cowpeas (Vigna sinensis L.) were germinated according to Kavas and El (1992) with slight modifications. After removal of the broken seeds and extraneous materials, seeds were steeped in tap water containing $0.5 \%$ hypochlorite (v/v) for $2 \mathrm{~min}$. Then they were washed with tap water and soaked in 3 volumes of water at room temperature for $8 \mathrm{~h}$. After soaking, lentils and cowpeas were allowed to germinate in an incubator (FOC 225E, Velp Scientifica Italy) at $30^{\circ} \mathrm{C}$ for 5 days and 3 days, respectively. Duration of germination was determined according to the length of coleoptiles (approximately $7 \mathrm{~cm}$ ). Sprouts and seeds were used freshly in the preparation of vegetable mix.

\section{Isolation of caseinomacropeptide from whey}

Caseinomacropeptide was isolated from whey with a modified method described by Martín-Diana et al. (2002). At first, $\mathrm{pH}$ was adjusted to 5.2 and then rennet sweet whey was heated at $90-95^{\circ} \mathrm{C}$ for $1 \mathrm{~h}$. The denaturated proteins were removed by centrifugation (Thermo Scientific CL31R, Germany) at $10000 \mathrm{~g}$ and $4^{\circ} \mathrm{C}$ for 20 min, and the supernatant containing CMP was concentrated by ultrafiltration (Sartocon Slice Ultrafiltration System, Sartorius Stedim Biotech GmbH, Germany) with $\mathrm{MWCO} 10 \mathrm{kDa}$ at $50^{\circ} \mathrm{C}$. The retentate volume was increased with water to carry out a continuous diafiltration process to eliminate the excess of lactose and minerals. The retentate containing CMP was then concentrated, lyophilized $\left(-45^{\circ} \mathrm{C}, 0.045\right.$ bar Labconco 2.5 FreeZone, USA) and stored at $-20^{\circ} \mathrm{C}$.

\section{Salad dressing preparation}

Salad dressing is composed of parsley (Petroselinum crispum) (3\%), basil (Ocimum basilicum) (3\%), dill (Anethum graveolens) (3\%), mint (Menta longifolia) (3\%), lemon juice (Citrus lemon) (11.5\%), vinegar $(3 \%)$, pomegranate syrup (7\%), olive oil (6\%), CMP (4\%), germinated seed and sprouts of lentil (Lens culinaris L.) (3.5\%) and cowpea (Vigna unguiculata L. Walp.) (3.5\%), mustard $(3 \%)$, honey $(3 \%)$, garlic $(0.1 \%)$ and salt $(0.1 \%)$. The mixture was completed to $100 \mathrm{~g}$ with water and homogenized (Figure 1).

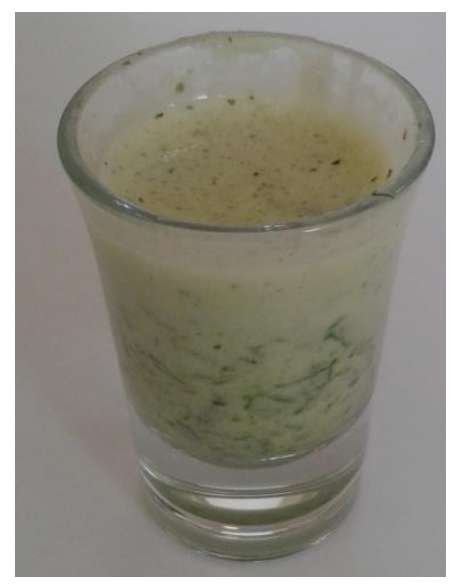

Figure 1 Salad dressing

Hedonic test was used for sensory evaluation. Ten panelists were asked to evaluate taste using 5 score sheet from dislike to like (Altuğ and Elmaci, 2005). The overall score was 4.3.

\section{Proximate composition}

Moisture, total sugars, protein and vitamin $\mathrm{C}$ contents of the sample were determined by gravimetrically in vacuum oven, Lane-Eynon method, Kjeldahl method and titrimetric method, respectively according to AOAC (2000).

\section{Total phenols $(T P)$}

The extraction of phenolic compounds was carried out according to Vinson et al. (1995). Total phenol content of 
salad dressing was determined using Folin-Ciocalteau's method (Vinson et al., 1995; Karakaya et al., 2001). Absorbance readings were taken at $765 \mathrm{~nm}$ against distilled water as a blank. Total phenol content of the sample was expressed as $\mathrm{mg}(+)$-catechin equivalents (CE) in $100 \mathrm{~g}$ sample.

\section{Total flavonoids $(T F)$}

Flavonoids were extracted by cold extraction procedure. A method proposed by Heimler et al. (2005) was used to determine TF of the sample. Absorbance was read at $510 \mathrm{~nm}$ against reagent blank. TF of the sample was expressed as mg (+)-catechin equivalents (CE) in 100 g sample.

The total non-flavonoid phenolics (n-FP) content of the sample was calculated by subtracting TF from TP.

\section{Antioxidant activity (AA)}

Antioxidant activities of the salad dressing were evaluated with two different assays depending on the reaction mechanism. The free radical scavenging activity was tested using DPPH radical. This method is based on electron transfer mechanism (Brand-Williams et al., 1995). Oxygen radical absorbance capacity (ORAC) method based on hydrogen atom transfer was applied as a second assay (Ou et al., 2001). The antioxidant activity results were expressed as Trolox equivalents (mM TEAC/100 g sample).

\section{Expected glycemic index (eGI)}

Expected glycemic index was determined by measuring in vitro starch digestibility of the sample (Englyst et al., 2000). The rate of starch digestion was expressed as the percentage of total starch hydrolyzed at different times $(20,60,90,120$, and $180 \mathrm{~min})$. An equation $\mathrm{C}=\mathrm{C}_{\infty}\left(1-\mathrm{e}^{-\mathrm{kt}}\right)$ was used to describe the kinetics of starch hydrolysis where $\mathrm{C}, \mathrm{C}_{\infty}$, and $\mathrm{k}$ were the hydrolysis degree at each time, the maximum hydrolysis extent, and the kinetic constant, respectively. Hydrolysis index (HI) was obtained by dividing the area under the hydrolysis curve of the sample by the area obtained for white bread. The eGI was calculated using the equation 1 described by Goni et al., 1997).

$$
\mathrm{eGI}=39.71+0.549(\mathrm{HI})
$$

\section{In vitro antidiabetic activity}

Antidiabetic activity of salad dressing was determined by measuring inhibitory effects of the sample on $\alpha$ glucosidase and $\alpha$-amylase enzymes in vitro. For the extraction, 3-5 g sample was vortexed with $25 \mathrm{~mL}$ phosphate buffered saline (PBS) (50 mM, pH 6.9, including $6.85 \mathrm{mM} \mathrm{NaCl}$ ) for $1.5 \mathrm{~min}$ at $3000 / \mathrm{min}$. The mixture was centrifuged at $10000 \mathrm{~g}$ for $10 \mathrm{~min}$ and the supernatant was filtered. Extraction was repeated and the supernatants were combined and used for the analysis.

$\alpha$-Glucosidase Inhibition Assay: $\alpha$-Glucosidase (AG) inhibition assay was conducted according to Koh et al. (2010) with slight modifications. Briefly, $340 \mu \mathrm{L}$ of the sample, at different concentrations, were incubated with $20 \mu \mathrm{L}$ of $\mathrm{AG}$ solution $(25 \mathrm{mg} / \mathrm{mL})$ at $37^{\circ} \mathrm{C}$. Then, $40 \mu \mathrm{L}$ of PNPG solution $(30 \mathrm{mM})$ were added to initiate the digestion. After $15 \mathrm{~min}, 10 \mu \mathrm{L}$ of EDTA $(0.1 \mathrm{mM})$ were added to prevent interaction between iron, which vegetables could possibly contain, and p-nitrophenol. For reaction termination $1 \mathrm{mM} \mathrm{Na} \mathrm{CO}_{3}(190 \mu \mathrm{L})$ was added. Absorbance at $400 \mathrm{~nm}$ was measured by using a Microplate reader (Thermo Scientific Varioskan Flash, Finland). Percentage of AG inhibition was calculated with Eq. (2). The concentration of the sample required to produce a $50 \%$ inhibition of the initial rate of reaction was calculated by interpolation of percentage inhibitions against different sample concentrations.

$$
\begin{aligned}
& \text { Inhibition }(\%)=100 \times \frac{\left\lfloor\left(A_{c}-A_{c b}\right)-\left(A_{s}-A_{s b}\right)\right\rfloor}{\left(A_{c}-A_{c b}\right)} \\
& A_{c}=A_{\text {control }} ; A_{c b}=A_{\text {control blank }} ; \\
& A_{s}=A_{\text {sample }} ; A_{s b}=A_{\text {sampleblank }}
\end{aligned}
$$

Where; $\mathrm{A}_{\text {control }}, \mathrm{A}_{\text {controlblank }}, \mathrm{A}_{\text {sample }}, \mathrm{A}_{\text {sampleblank }}$ refer to absorbance reading of reaction mixture containing active enzyme and buffer, inactive enzyme and buffer, active enzyme and sample (inhibitor) and inactive enzyme and sample (inhibitor), respectively. Substrate was present in all mixtures.

$\alpha$-Amylase inhibition assay: $\alpha$-Amylase inhibition assay was conducted according to Koh et al. (2010) and Yang et al. (2012). $820 \mu \mathrm{L}$ of the sample, at different concentrations, were incubated with $100 \mu \mathrm{L} \alpha$-amylase. Then $80 \mu \mathrm{L}$ of the potato starch solution in PBS (1\%) were added, and the whole mixture incubated at $37^{\circ} \mathrm{C}$. For reaction termination $500 \mu \mathrm{L}$ of $\mathrm{HCl}(10 \%)$ were added. To determine retained starch in the medium, $150 \mu \mathrm{L}$ of iodine solution $\left(0.0025 \mathrm{M} \mathrm{I}_{2} / 0.0065 \mathrm{M} \mathrm{KI}\right)$ were used. Absorbance at $620 \mathrm{~nm}$ was measured by using a Microplate reader (Thermo Scientific Varioskan Flash, Finland). Percentage of amylase inhibition was calculated by using $\mathrm{Eq} 2 . \mathrm{IC}_{50}$ of the sample was determined by interpolation from the curve.

\section{In vitro angiotensin converting enzyme (ACE)} inhibitory activity

ACE inhibitory activities of the samples were determined by the method proposed by Oboh et al. (2012) with minor modifications. Briefly, $100 \mu \mathrm{L}$ ACE $(25$ $\mathrm{U} / \mathrm{mL}$ ) solution and $40 \mu \mathrm{L}$ samples prepared as different concentrations were incubated at $37^{\circ} \mathrm{C}$ for $15 \mathrm{~min}$. The enzymatic reaction was initiated by adding the substrate Hip-His-Leu (100 $\mu \mathrm{L}$ of $8.33 \mathrm{mM})$ and $0.3 \mathrm{M} \mathrm{NaCl}$ in 50 $\mathrm{mM}$ sodium borate buffer $(\mathrm{pH} 8.3)$ to the mixture. After incubation for $15 \mathrm{~min}$ at $37^{\circ} \mathrm{C}$, the reaction was stopped by adding $150 \mu \mathrm{L} 1 \mathrm{M} \mathrm{HCl} .1000 \mu \mathrm{L}$ ethyl acetate was added to each tube and tubes were subjected to centrifugation (1500 g for $15 \mathrm{~min}$ ). After centrifugation $750 \mu \mathrm{L}$ of ethyl acetate layer was transferred to a clean test tube and evaporated. The residue was redissolved in distilled water and its absorbance was measured at 228 $\mathrm{nm}$. The control included all other reagents and the enzyme with the exception of the test sample. The ACE inhibitory activities were expressed as percentage inhibition by using equation 3 . In addition $\mathrm{IC}_{50}$ values of the samples were calculated. 


$$
\operatorname{Inhibition}(\%)=100 \times \frac{\left(A_{c}-A_{s}\right)}{A_{c}}
$$

$$
\mathrm{A}_{\mathrm{c}}=\mathrm{A}_{\mathrm{control}} ; \mathrm{A}_{\mathrm{s}}=\mathrm{A}_{\text {sample }}
$$

Where; $\mathrm{A}_{\text {control}}$ : Absorbance value recorded for control, $\mathrm{A}_{\text {sample }}$ : Absorbance value recorded for sample

\section{In vitro bile acid binding capacity}

Cholesterol-lowering effect of the sample can be predicted by measuring their in vitro bile acid binding capacity based on positive correlations found between in vitro and in vivo studies (Kahlon et al., 2008). The in vitro bile acid binding procedure was performed as described by Kahlon and Smith (2007) with slight modifications. The stock bile acid mixture contained glycocholic acid $(0.27 \mathrm{mM})$, deoxycholic acid $(0.63 \mathrm{mM})$, taurocholic acid $(0.27 \mathrm{mM})$, and cholic acid $(0.63 \mathrm{mM})$ in $\mathrm{pH} 6.3,0.1 \mathrm{M}$ PBS. This stock solution of $1.8 \mathrm{mM}$ was diluted to the working solution $(0.72 \mu \mathrm{M})$ just prior to each assay.

The $\mathrm{pH}$ of the samples was adjusted to 2 with $1 \mathrm{~mL}$ of $0.01 \mathrm{M} \mathrm{HCl}$ and they were incubated for $1 \mathrm{~h}$ in a $37^{\circ} \mathrm{C}$ shaker water bath. After incubation, the mixture $\mathrm{pH}$ was adjusted to 6.3 with $0.1 \mathrm{~mL}$ of $0.1 \mathrm{M} \mathrm{NaOH}$. Bile acid mixture working solution $(4 \mathrm{~mL}, 0.72 \mu \mathrm{M})$ in a $0.1 \mathrm{M}$ PBS (pH 6.3) was added to each test sample, whereas only PBS (4 mL, 0.1 M, pH 6.3) was added to the individual substrate blanks. After the addition of $5 \mathrm{~mL}$ of porcine pancreatin, tubes were incubated for $1 \mathrm{~h}$ in a $37^{\circ} \mathrm{C}$ shaker bath. Mixtures were centrifuged at $9000 \mathrm{~g}$ for 10 min. Cellulose (a non-bile acid binding fiber) and cholestyramine (a bile acid binding anionic resin) were used as the negative and positive controls, respectively. Bile acids were analyzed using Trinity Biotech bile acids procedure No. 450 (Trinity Biotech Distribution, St. Louis, MO) using Microplate reader (Thermo Scientific Varioskan Flash, Finland). Values were determined from a standard curve obtained by analyzing Trinity Biotech bile acid calibrators (No. 450-11) at 5, 25, 50, 100 and $200 \mu \mathrm{M}$.

\section{Statistical analysis}

All analyses were performed in triplicate. The software IBM SPSS Statistics version 21 is used for statistical analysis. The distribution of variables (test of normality) was tested using Shapiro-Wilk test. Results were given as mean \pm standard deviation.

\section{Results and Discussion}

\section{Isolation of CMP from whey}

Whey has been considered a novel raw material for many purposes recently. Next to the whey proteins, the CMP present in sweet whey is a valuable constituent for both its functional properties as well as its specific nutritive value (Tolkach and Kulozik, 2005). The protein fractions of bovine sweet whey obtained from kashkaval cheese production as waste and CMP isolate were shown in Figure 2. CMP peaks (GMP and nGMP) were compared with the RP-HPLC chromatogram of CMP (Davisco Food International), which is used as food supplement. Since the main goal was to isolate CMP from sweet cheese whey, the other whey proteins, proteose peptone (PP), $\alpha$-lactalbumin $(\alpha$-lac), bovine serum albumin (BSA), $\beta$-lactoglobulin $(\beta-\lg )$, immunoglobulin $(\mathrm{IgG})$ were identified by comparing retention times reported in the previous studies and in the study of Elgar et al. (2000).

\section{The composition of salad dressing}

The nutritional importance of sauces and salad dressings has been taking great attention not only because they are commonly used in the everyday life of many consumers, but also their potential use as excipient foods. Table 1 represented the composition of salad dressing. Salad dressing met $16.08 \%$ of daily reference intake of vitamin C. Although this value was very high, it should be evaluated in serving size due to $100 \mathrm{~g}$ was very high to consume. According to Turkish Food Codex Regulation on Labelling, a serving size of salad dressing is $20 \mathrm{~g}$. Correspondingly, consumption of one serving of salad dressing could supply the vitamin $\mathrm{C}$ requirement by $3.22 \%$. Energy value of salad dressing was $111 \mathrm{kcal} / 100 \mathrm{~g}$ and $11.41 \%$ of the energy value of the salad dressing was provided by protein. Energy value of salad dressing provided by protein was very close to the value (12\%) for making a nutrition claim as "source of protein" according to Regulation 1924/2006/EC and Turkish Food Codex (Anonymous, 2011; Anonymous, 2014). Increase in protein content than its counterparts showed that CMP and germinated seed and sprouts were very good valueadded food ingredients because of their high nutritional value. In the case of phenolic compounds $24.49 \%$ of total phenols (79 mg CE/100 g) was composed of flavonoids. Literature survey (Science Direct and Web of Science Database) showed that data regarding phenolic contents of salad dressings are scarce. In one study, total phenol contents of Italian and Thousand Island salad dressings fortified with wine grape pomace were reported as 58.5 $\mathrm{mg}$ GAE/100 g and $134 \mathrm{mg}$ GAE/100 g, respectively (Tseng and Zhao, 2013).

In vitro antioxidant, ACE inhibitory, antidiabetic and bile acid binding activities

Table 2 represented the antioxidant, ACE inhibitory, antidiabetic activities and expected glycemic index (eGI) of salad dressing. Salad dressing displayed higher antioxidant activity against DPPH radical than that of ORAC value. This result showed that salad dressing was more effective on electron quenching than hydrogen atom quenching. According to the hypothesize proposed by Roy et al. (2010) substances having a lower antioxidant capacity in the ORAC assay compared with that in DPPH assays may pertain to a pro-oxidant effect by generating reactive oxygen species in an aqueous buffer, at a physiological $\mathrm{pH}$. They also stated that substances exhibiting lower antioxidant capacity in the ORAC assay compared with that in the DPPH assay are powerful prooxidants compared with the substances showing a higher antioxidant activity in the ORAC assay than that in the DPPH assay. Studies in the web of science database have been intensified on rheological and structural properties, and oxidative stability of salad dressings. Rasmussen et al. (2008) reported that French salad dressings incorporating honey provided protection against oxidation to a degree similar to that of EDTA, as determined by 
peroxide value and p-anisidine value. Incorporating herbs, spices and seasoned salts to salad dressings composed of olive oil and/or vinegar caused increase in antioxidant activity (Ninfali et al., 2005).

In this study salad dressing inhibited ACE by approximately 37\%. Because ACE inhibitory effect was below $50 \%, \mathrm{IC}_{50}$ value of salad dressing could not be estimated. In general, ACE inhibitory activity of foods has been associated with dietary peptides (Kancabas and Karakaya, 2013). Caseinomacropeptide, one of the bioactive peptides, has been shown to affect digestive secretions and to inhibit gastrin (Yvon et al., 1994). During germination seeds absorb water, which triggers a series of complex reactions. The main reaction is hydrolyses of storage proteins by endopeptidases to produce low molecular weight peptides that will generate the tissues and organs of the new plant. de Souza Rocha et al. (2014) reported that after $24 \mathrm{~h}$ germination of cowpea a mixture of peptides with dipeptidyl peptidase-IV (DPPIV) inhibitory activity was produced. Inhibition of DPPIV has been used in current type II diabetes treatment. In the case of lentil proteins, mainly composed of globulins, recent studies have shown that lentil protein hydrolysates exhibit ACE inhibitory activity (Barbana and Boye, 2011). In addition, recent report has addressed ACE inhibitory activities of polyphenols that dietary plants contain (Patten et al., 2012).

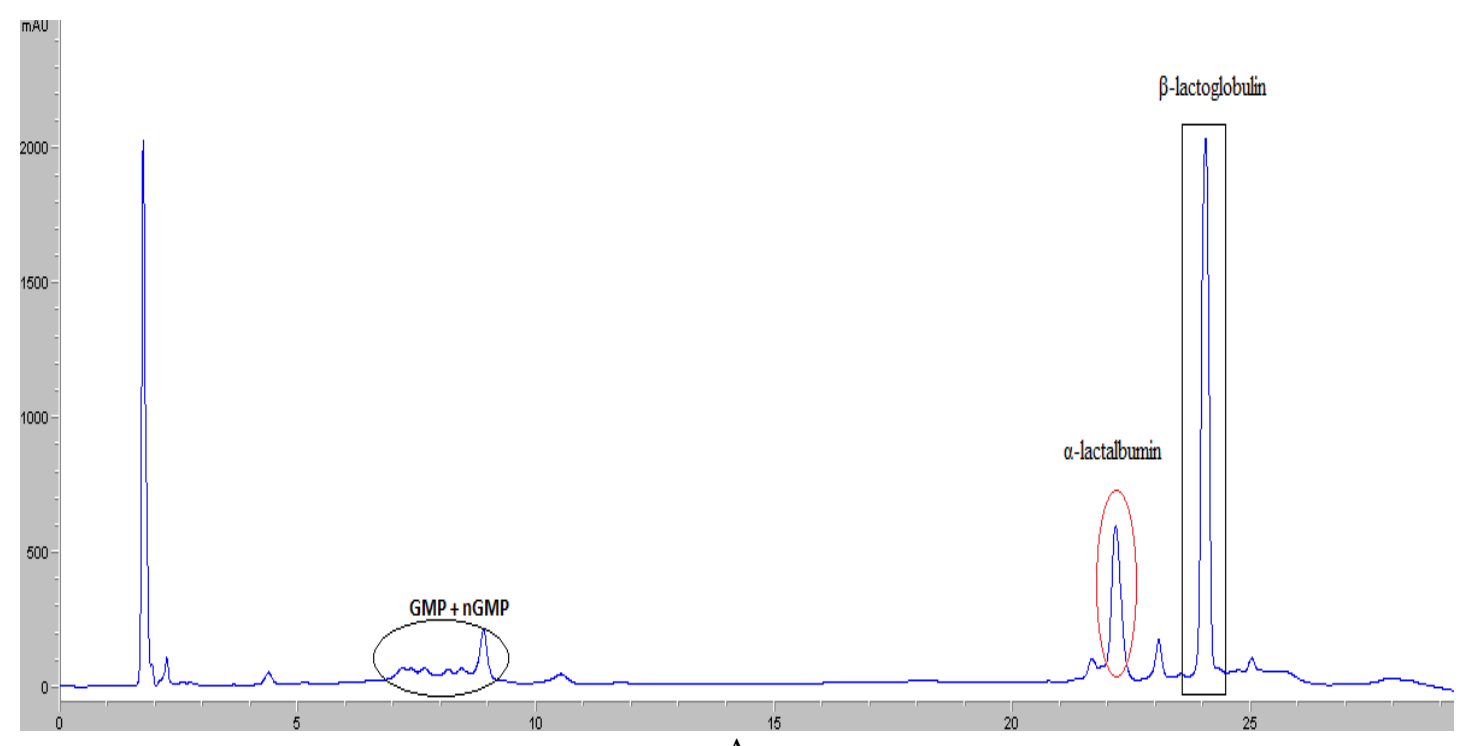

A

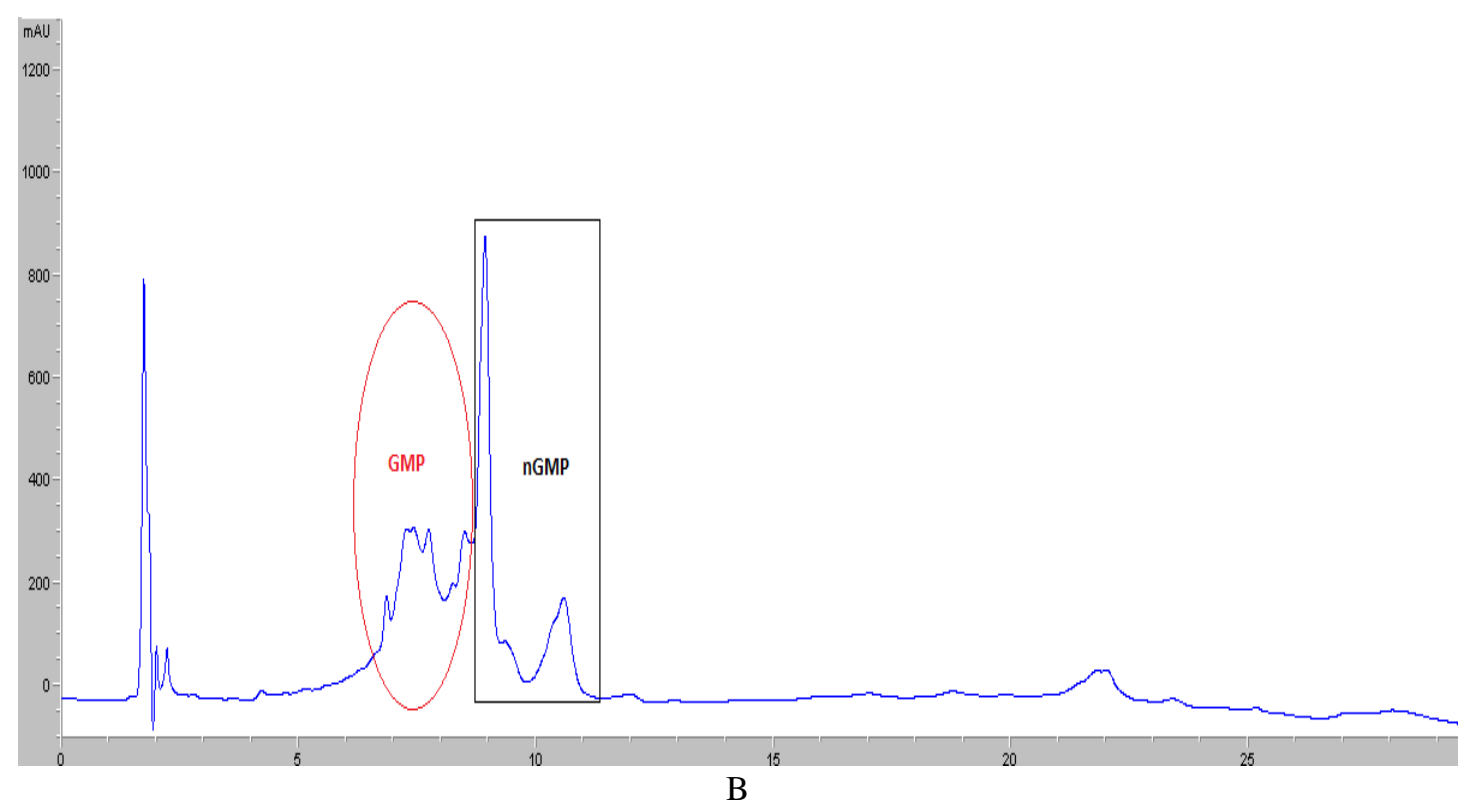

Figure 2 A: Protein profile of whey; B: Protein profile of CMP isolate obtained from whey (GMP: Glucomacropeptit, nGMP: non-glycosylated GMP, CMP: GMP+nGMP) 
Table 1 The composition and TF, TP, and n-FP contents of salad dressing

\begin{tabular}{l|c}
\hline & Salad dressing* \\
\hline Dry matter $(\%)$ & $24.11 \pm 0.55$ \\
Ash $(\%)$ & $0.63 \pm 0.03$ \\
Total sugars $(\%)$ & $4.97 \pm 0.25$ \\
Total protein $(\%)$ & $3.16 \pm 0.02$ \\
Vitamin C $(\mathrm{mg} / 100 \mathrm{~g})$ & $12.8 \pm 1.47$ \\
TP $(\mathrm{mg} \mathrm{CE} * / 100 \mathrm{~g})$ & $79 \pm 19$ \\
TF $(\mathrm{mg} \mathrm{CE} / 100 \mathrm{~g})$ & $19 \pm 3$ \\
n-FP $(\mathrm{mg} \mathrm{CE} / 100 \mathrm{~g})$ & $60 \pm 22$ \\
\hline
\end{tabular}

* Values were given as mean $\pm \mathrm{SD}(\mathrm{n}=6)$. TF, total flavonoids; TP, total phenols; n-FP, total non-flavonoids phenolics; ** $\mathrm{CE}$, catechin equivalent

Table 2 Antioxidant, anti-hypertensive, antidiabetic activities and expected glycemic index of salad dressing*

\begin{tabular}{l|lc}
\hline & \multicolumn{1}{|c}{ Salad dressing } \\
\hline Antioxidant activity (mM & DPPH & $130 \pm 8$ \\
Trolox/100 g sample) & ORAC & $72 \pm 3$ \\
\hline ACE inhibition $(\%)$ & $37 \pm 9$ \\
$\alpha-$ Glucosidase inhibition & $1.77 \pm 0.10$ \\
$\mathrm{IC}_{50}$ ** (mg protein/mL) & \\
$\alpha-$ Amylase inhibition & $2.40 \pm 0.25$ \\
$\mathrm{IC}_{50}(\mathrm{mg}$ protein/mL) & $74.0 \pm 4.98$ \\
$\mathrm{eGI}^{1}$ & \\
\hline * Values were given as mean $\pm \mathrm{SD}(\mathrm{n}=6) ; * * \mathrm{IC}_{50}:$ Concentration of
\end{tabular}

$*$ Values were given as mean $\pm \mathrm{SD}(\mathrm{n}=6)$; $* * \mathrm{IC}_{50}$ : Concentration of protein needed to inhibit $50 \%$ of original ACE activity; ${ }^{1}$ Glycemic index was calculated using glucose as a reference food.

Expected glycemic index of salad dressing was 74.0 (Table 2). According to classification of GI salad dressing belongs to high GI foods. Contrary to, salad dressing inhibited $\alpha$-glucosidase and $\alpha$-amylase with the $\mathrm{IC}_{50}$ values $1.77 \mathrm{mg}$ protein $/ \mathrm{mL}$ and $2.40 \mathrm{mg}$ protein $/ \mathrm{mL}$, respectively. The presence of $\alpha$-glucosidase and $\alpha$ amylase inhibitors in the diet has been recognized as a proper approach in the retardation of digestion of dietary carbohydrates and accordingly, controlling postprandial hyperglycemia. Pancreatic $\alpha$-amylase hydrolyses starch into disaccharides and oligosaccharides before intestinal $\alpha$-glucosidase catalyzes the breakdown of disaccharides to liberate glucose, which is later absorbed into the blood circulation. Inhibition of these enzymes may slow down the breakdown of starch in the gastro-intestinal tract, thus reducing postprandial hyperglycemia (Kwon et al., 2007). Studies indicate that an effective strategy in the management of type II diabetes is the strong inhibition of intestinal $\alpha$-glucosidases and mild inhibition of pancreatic $\alpha$-amylase. Excessive inhibition of $\alpha$-amylase can result in the abnormal bacterial fermentation of undigested carbohydrates in the colon (Oboh et al., 2012). From this point of view salad dressing can be a good choice to control postprandial hyperglycemia, although its GI is high. Literature survey (Science Direct and Web of Science database) showed that there were no studies regarding $\alpha$-amylase and $\alpha$-glucosidase inhibitory effects of salad dressings.

Relative to cholestyramine, bile acid binding capacity of salad dressing is $39.85 \%$. This capacity is higher than those of many foods reported in literature including fermented vegetable juice $(7 \%)$, steam cooked broccoli $(8.1 \%)$ and Brussels sprouts (10.4\%) (Kahlon et al., 2008; Simsek et al., 2014). Although reduced fat absorption and cholesterol reduction can have a beneficial effect on human health, it is important whether the degree of bile acid binding is high enough to impair lipophilic micronutrients' absorption. A minimal bile concentration for optimal transfer of lutein and $\beta$-carotene from lipid droplets into mixed micelles was found as approximately $5 \mathrm{mM}$ (Biehler et al., 2011). Bile salt concentration in the small intestine ranges from 4 to $20 \mathrm{mM}$, depending on whether the subject is in the fasted or fed state. In the case of $20 \mathrm{mM}$ bile salt concentration in the small intestine salad dressing could bind approximately $8 \mathrm{mM}$ bile salt. Even in this condition, $12 \mathrm{mM}$ bile salt would still available for micellarization. Salad dressing with cholesterol-lowering effect was patented by Dartey et al. (2000). The ingredients responsible for cholesterollowering effect of another patented salad dressing were presented as soya protein, flax seed oil and vinegar (McKeown, 2000).

In conclusion, salad dressing produced in this study can be a good example to excipient foods with enhanced health benefits. When this salad dressing combined with various salads, can enhance carotenoid bioavailability due to its olive oil content, antioxidant capacity due to its phytochemical content, and can help to manage type II diabetes and hypertension due to its phytochemical and protein contents. The advantages of the dressing as an excipient food are its convenience for incorporating into various salads, desirable sensory characteristics and beneficial health effects. In addition, it can be regularly incorporated into a daily diet with cost effective, which is about $4.5 £$ per $250 \mathrm{~mL}$.

\section{Acknowledgements}

The authors participate in the COST Action FA1005 INFOGEST. The financial support by The Scientific and Technological Research Council of Turkey-TUBITAK (Project no: 1100072) is gratefully acknowledged.

\section{References}

Akillioglu HG, Karakaya S. 2010. Changes in total phenols, total flavonoids and antioxidant activities of common beans and pinto beans after soaking, cooking and in vitro digestion process. Food Sci Biotech., 19:633-639.

Altuğ T, Elmaci Y. 2005. Gidalarda Duyusal Değerlendirme. Bornova, İzmir. Meta Basım. 975-97408-1-8.

Anonymous. 2011. Turkish Food Codex-Regulations for labelling regulations. Official Gazette, No:28906.

Anonymous. 2014. Regulation 1924/2006/EC of 30 December 2006 of the European parliament and of the council on nutrition and health claims made on foods. Official Journal of the European Union, L 404, 9-25.

AOAC. 2000. Official methods of analysis $\left(17^{\text {th }}\right.$ ed.). Washington: Association of Official Analytical Chemists, 2000.

Barbana C, Boye JI. 2011. Angiotensin-converting enzyme inhibitory properties of lentil protein hydrolysates: Determination of the kinetics of inhibition. Food Chem., 127:94-101.

Biehler E, Kaulmann A, Hoffmann L, Krause E, Bohn T. 2011. Dietary and host-related factors influencing carotenoid bioaccessibility from spinach (Spinacia oleracea). Food Chem., 125:1328-1334. 
Brand-Williams W, Cuvelier ME, Berset C. 1995. Use of a freeradical method to evaluate antioxidant activity. Food Sci Technol-Leb., 28:25-30.

Chen G, Wang H, Zhang X, Yang ST. 2014. Nutraceuticals and functional foods in the management of hyperlipidemia. Crit Rev Food Sci., 54:1180-1201.

Dartey CK, Higgins JD, Bruce RD, Burruano BT. 2000. Stable salad dressing. McNeil-PPC, Inc., United States Patent No: $6,123,978$.

de Souza Rocha T, Hernandez LMR, Chang YK, de Mejía EG. 2014. Impact of germination and enzymatic hydrolysis of cowpea bean (Vigna unguiculata) on the generation of peptides capable of inhibiting dipeptidyl peptidase IV. Food Res Int., 64:799-809.

Elgar DF, Norris CS, Ayers JS, Pritchard M, Otter DE, Palmano KP. 2000. Simultaneous separation and quantitation of the major bovine whey proteins including proteose peptone and caseinomacropeptide by reversed-phase high-performance liquid chromatography on polystyrene-divinylbenzene. J Chromatogr A., 878:183-196.

Englyst KN, Hudson GJ, Englyst HN. 2000. Starch Analysis in Food. In: (Meyers RA). Encyclopedia of Analytical Chemistry. Chichester: John Wiley \& Sons Ltd. pp: 4246-4262.

Goni I, Garcia-Alonsoand A, Saura-Calixto FA. 1997. A starch hydrolysis procedure to estimate glycemic index. Nutr Res., 17:427-437.

Guangchang P, Xie J, Chen Q, Hu Z. 2012. How functional foods play critical roles in human health. Food Sci Hum Well. $1(1): 26-60$.

Heimler D, Vignolini P. Dini MG, Romani A. 2005. Rapid tests to assess the antioxidant activity of Phaseolus vulgaris L. dry beans. J Agric Food Chem., 53:3053-3056.

Kahlon TS, Smith GE. 2007. In vitro binding of bile acids by bananas, peaches, pineapple, grapes, pears, apricots and nectarines. Food Chem., 101:1046-1051.

Kahlon TS, Chiu MM, Chapman HM. 2008. Steam cooking significantly improves in vitro bile acid binding of collard greens, kale, mustard greens, broccoli, green bell pepper, and cabbage. Nutr Res., 28:351-537.

Kancabas A, Karakaya S. 2013. Angiotensin-converting enzyme (ACE)-inhibitory activity of boza, a traditional fermented beverage. J Sci Food Agric., 93:641-645.

Karakaya S, El SN, Taş AA. 2001. Antioxidant activity of some foods containing phenolic compounds. Int J Food Sci Nutr., 52:501-508.

Kavas A, El SN. 1992. Changes in nutritive value of lentils and mung beans during germination. Chem Mikrobiol Technol Lebens., 14:3-9.

Koh LW, Wog LL, Loo YY, Kasapis S, Huang D. 2010. Evaluation of different teas against starch digestibility by mammalian glycosidases. J Agric Food Chem., 58:148-154.

Kwon YI, Apostolidis E, Kim YC, Shetty K. 2007. Health benefits of traditional corn, beans, and pumpkin: in vitro studies for hyperglycemia and hypertension management. J Med Foods, 10:266-275.

Magrone T, de Heredia FP, Jirillo E, Morabito G, Marcos A, Serafini M. 2013. Functional foods and nutraceuticals as therapeutic tools for the treatment of diet-related diseases. C J Physiol Pharm., 91(6):387-396.
Martín-Diana AB, Fragaand MJ, Fontecha J. 2002. Isolation and characterisation of caseinomacropeptide from bovine, ovine and caprine cheese whey. Eur Food Res Int., 214:282-286.

McClements DJ, Xiao H. 2014. Excipient foods: Designing food matrices that improve the oral bioavailability of pharmaceuticals and nutraceuticals. Food Func., 5:1320-1333.

McClements DJ. 2015. Enhancing nutraceutical bioavailability through food matrix design. Curr Opin Food Sci., 4:1-6.

McKeown MJ. 2000. Mixture of flax oil, tofu and vinegar. McNeilPPC, Inc., United States Patent No: 6,090,432.

Ninfali P, Mea G, Giorgini S, Rocchi , Bacchiocca M. 2005. Antioxidant capacity of vegetables, spices and dressings relevant to nutrition. Brit J Nutr., 93:257-266.

Oboh G, Ademiluyi AO, Akinyemi AJ, Henle T, Saliuand JA, Schwarzenbolz U. 2012. Inhibitory effect of polyphenol-rich extracts of juite leaf (Corchorus olitorius) on key enzyme 73 linked to type 2 diabetes ( $\alpha$-amylase and $\alpha$-glucosidase) and hypertension (angiotensin i converting) in vitro. J Func Foods, 4:450-458.

Ou B, Hampsch-Woodill M, Prior RL. 2001. Development and validation of an improved oxygen radical absorbance capacity assay sing fluorescein as the fluorescent probe. J Agric. Food Chem., 49:4619-4626.

Patten GS, Abeywardena MY, Head RJ, Bennett LE. 2012. Processed dietary plants demonstrate broad capacity for angiotensin converting enzyme and angiotensin ii receptor binding inhibition in vitro. J Func Foods., 4:851-863.

Rasmussen CN, Wang XH, Leung S, Andrae-Nightingale LM, Schmidt SJ, Engeseth NJ. 2008. Selection and use of honey as an antioxidant in a French salad dressing system. J Agric Food Chem., 56:8650-8657.

Roy MK, Koide M, Rao TP, Okubo T, Ogasawara Y, Juneja LR. 2010. ORAC and DPPH assay comparison to assess antioxidant capacity of tea infusions: relationship between total polyphenol and individual catechin content. Int J Food Sci Nutr., 61(2):10924.

Simsek S, El SN, Kancabas Kilinc A, Karakaya S. 2014. Vegetable and fermented vegetable juices containing germinated seeds and sprouts of lentil and cowpea. Food Chem., 156:289-295.

Thomä-Worringer C, Sørensen J, López-Fandiño RJ. 2006. Health effects and technological features of caseinomacropeptide. Int Dairy J., 16:1324-1333.

Tolkach A, Kulozik UJ. 2005. Fractionation of whey proteins and caseinomacropeptide by means of enzymatic crosslinking and membrane separation techniques. J Food Eng., 67:13-20.

Tseng A, Zhao Y. 2013. Wine grape pomace as antioxidant dietary fibre for enhancing nutritional value and improving storability of yogurt and salad dressing. Food Chem., 138:356-365.

Vinson JA, Dabbagh YA, Mamdouh MS, Jang J. 1995. Plant flavonoids, especially tea flavonols are powerful antioxidants using an in vitro oxidant model for heart disease. J Agric Food Chem., 43:2800-2802.

Yang XW, Huang MZ, Jin YS, Sun LN, Songand Y, Chen HS. 2012. Phenolics from Bidens bipinnata and their amylase inhibitory properties. Fitoterapia, 83:1169-1175.

Yvon M, Beucher S, Guilloteau P, Le Huerou-Luron I, Corring T. 1994. Effects of caseinomacropeptide (CMP) on digestion regulation. Reprod Nutr Dev., 34(6):527-537. 